\title{
Expression of Apoptotic Genes after Autotransplantation of Vitrified Rat Ovary Encapsulated with Hyaluronic Acid Hydrogel
}

\author{
Maryam Akhavantaheri $^{\text {(iD) }}$,Mojtaba Rezazadeh valojerdi $^{2,3 *}$ (iD) Bita Ebrahimi $^{3}$ \\ ${ }^{1}$ Gametogenesis Research Center, Kashan University of Medical Sciences, Kashan, Iran \\ ${ }^{2}$ Dept of Anatomy, Faculty of Medical Sciences, Tarbiat Modares University, Tehran, Iran \\ ${ }^{3}$ Dept of Embryology, Reproductive Biomedicine Institute, Royan Institute, Tehran, Iran
}

Article Info A B S T R A C T

Article type:

Research article

\section{Article History:}

Received: 05 December 2020

Revised: 20 December 2020

Accepted: 18 July 2021

\section{* Correspondence to:}

Mojtaba Rezazadehvalojerdi

Dept of Anatomy, Faculty of

Medical Sciences, Tarbiat Modares

University, Tehran, Iran

Emailmr-valojerdi@modares.ac.ir
Introduction: Ischemia followed by apoptosis and follicles mortality are problems that occur after cryopreservation and ovarian tissue transplantation. The present study used hyaluronic acid hydrogel as a capsule to reduce ischemia and apoptosis in vitrified ovarian tissue transplantation of rats.

Material \& Methods: In total, 22 adult female rats ( 8-week old) with normal estrous cycle were ovariectomized, and their right ovaries were then vitrified and divided into two groups after being warmed, including vitrified-transplanted (VT) $(\mathrm{n}=11)$ and vitrified-encapsulated in hyaluronic acid hydrogel-transplanted (VT+HA) $(n=11)$ that were auto transplanted into the dorsal muscle. Following that, a daily vaginal smear was obtained from the 4th day after transplantation of the rats. The ovaries were removed at the end of the first estrous cycle (approximately 15 days after transplantation), and some apoptotic genes including P53, c-Myc, Bax, Bcl2 , and Caspase 3 were evaluated by the real-time PCR.

Findings: All transplants were completely successful (100\%). The results also showed that the expression of the P53, c-Myc, Bax, and Caspase 3 genes were higher in the VT group, compared to the VT+HA group. However, this difference was statistically significant only in the c-Myc gene $(\mathrm{P}<0.05)$.

Discussion \& Conclusion: Hyaluronic acid hydrogel was able to reduce the rate of apoptosis in the capsule group (VT+HA), compared to the noncapsule group (VT) after transplantation.

Keywords: Apoptosis, Hyaluronic acid hydrogel, Ovarian tissue, Ovarian transplantation, Vitrification

\section{$>$ How to cite this paper}

Akhavantaheri M, Rezazadehvalojerdi M, Ebrahimi B. Expression of Apoptotic Genes after Autotransplantation of Vitrified Rat Ovary Encapsulated with Hyaluronic Acid Hydrogel. Journal of Ilam University of Medical Sciences. 2022;29(5): 12-21. 


\section{ميزان بيان زنهاى آيويتوز يس از يِيوند اتوكرافت بافت تخمدان انجمادى

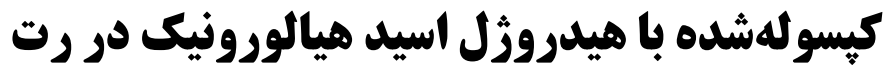

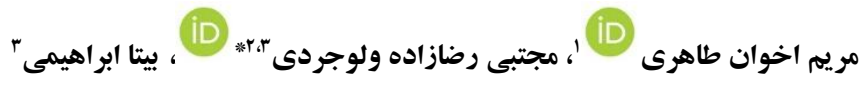
' مركز تحقيقات توليد سلولهاى جنسى، دانشكاه علوم يزشكى كاشان، كاشان، ايران

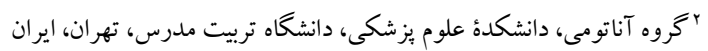

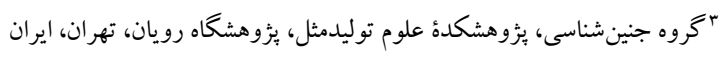

جكيده

مقدمه: ايسكمى و به دنبال آن، آيويتوز و مرگكومير فوليكولها از مشكلاتى است كه يّ از انجماد و وييوند بافت تخمدان رخ مىدهد. در مطالعه حاضر، با هدف كاهش ايسكمى و آيويتوز، از هيدروزل اسيد هيالورونيكك بهعنوان يكك كيسول در بافت تخمدان انجمادى-ييوندى رت استفاده شد. مواد و روش ها: Yr رت ماده بالغ ( م هفته) با سيكل استروس طبيعى، اوار كتومى گرديد و سيس تخمدان سمت راست

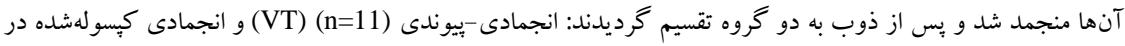

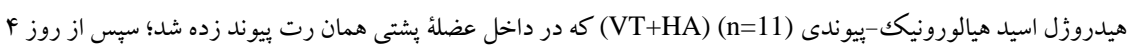

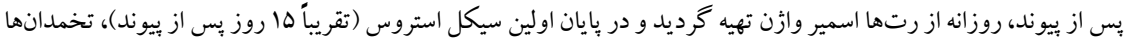
از بدن رتها خارج شد و با روش Real time PCR، بعضى از زنهاى دخيل در آيويتوز ازجمله P53، Bax ،c-Myc، 2، Caspase3

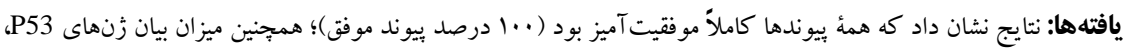

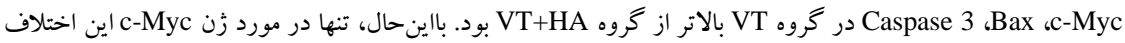
معنادار مشاهده شد (P<0.05). بحث و نتيجه كيرى: هيدروزل هيالورونيكك اسيد توانسته است يُ از بيوند، ميزان آيويتوز را در گروه داراى كڤيسول نسبت به گروه بدون كيسول (VT+HA)
تاريخ دريافت:

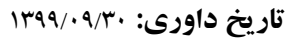
|F...F/rV تاريخ يذيرش:

$$
\begin{aligned}
& \text { نويسنده مسئول: } \\
& \text { مجتبى رضازاده ولوجردى }
\end{aligned}
$$

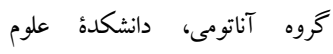
يزشكى، دانشگاه تربيت مدرس،

Email:

mr_valojerdi@modares.ac.ir

وازههاى كليدى: بافت تخمدان، انجماد شيشهاى، ييوند تخمدان، هيدروزل هيالورونيك اسيد، آيويتوز 
از سوى ديخر، موفقيت بيوند تخمدان به عوامل متعددى ازجمله محل بيوند، بستر عروقى، دورهُ ايسكمى، تكنيك به كار گر فنهشده در جراحى و عوامل محيطى دخيل در تسريع رگكزايى بستخى دارد (11). علىرغم

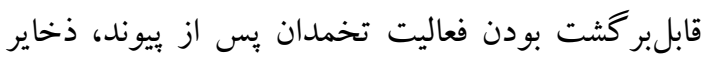

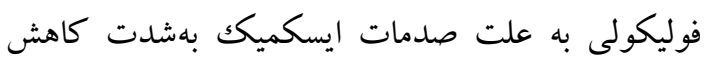

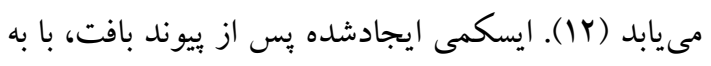

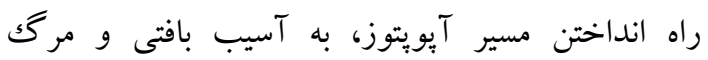

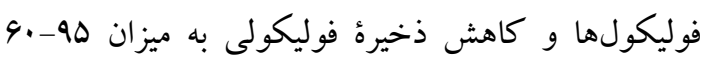

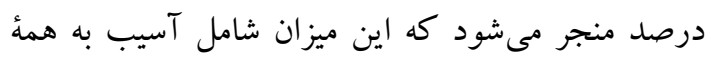
جمعيت فوليكولهاى در حال رشد است (سا). از آنجاكه كاهش آيويتوز بر شروع دوباره فعاليت تخمدانى مؤثر است، براى اين منظور تدابير مختلفى به كار گرفته شده

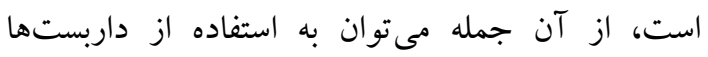

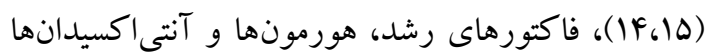
در حين يا پِ از يِيوند اشاره كرد (19)؛ بنابراين، در اين مطالعه از داربست اسيد هيالورونيك به بهنظور كاهش بـ آنش آيويتوز پس از يويوند استفاده شد.

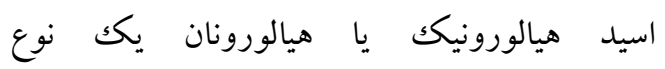
كليكوز آمينو كليكان است كه از واحدهاى تكرارشوندة د-كلوكورونيكك اسيد و ان-استيل كلوكز آمين تشكيلشده است و در بافت همبند مهرهداران يافت

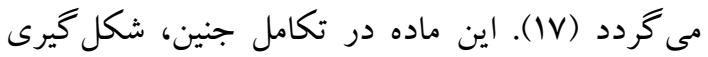

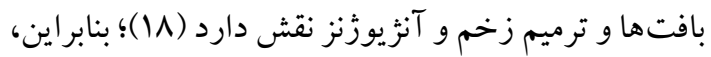
در اين مطالعه از هيدروزل اسيد هيالورونيك بهمنظور

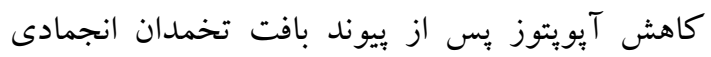
استفاده شد؛ همجنين براى بررسى بهتر و سادهتر زنهاى دخيل در آيويتوز، برخى مطالعات اين فرايند را به جهار

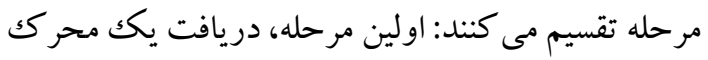
كشنده نيرومند توسط سلول است كه اين محرك مى تواند باتولوزيكك يا فيزيولوزيكك باشد؛ دومين مرحلة

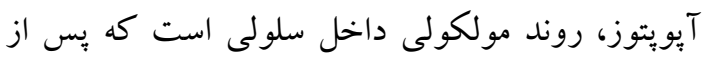
دريافت تحريكات خارج سلولى، در داخل سلول به راه
امروزه، تشخيص سرطان و درمانهاى آن شامل جراحى، شيمىدرمانى و راديوترابى عمر مبتلايان را افز ايش داده است؛ اما متأسفانه اين درمانها سبب آسيب به عروق خونى و فيبروز كانونى قشر تخمدان، از دست

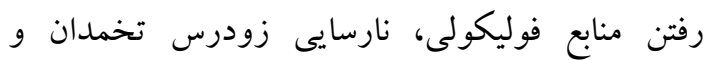
درنهايت كاهش بارورى مىشود (r-1). براى حفظ

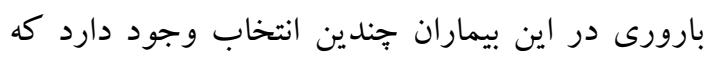

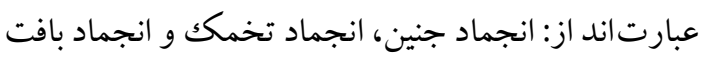

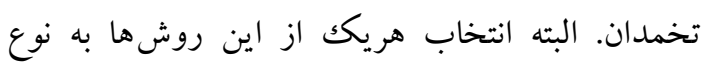

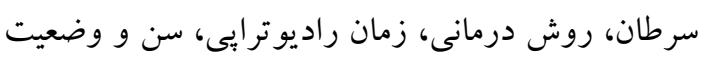

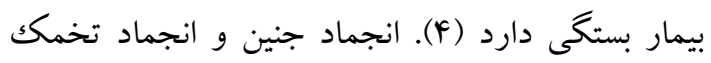

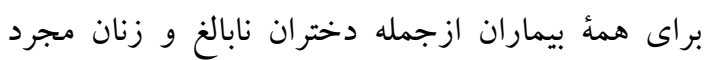
قابل استفاده نيست؛ بنابر اين، انجماد بافت تخمدان به عنوان

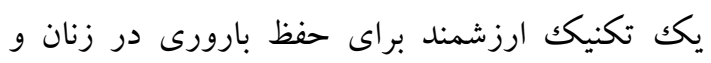
كودكانى است كه تحت درمانهاى سيتوتو كسيك إنى

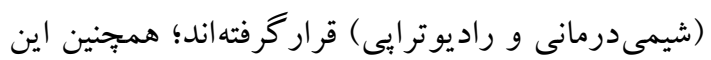
تكنيك براى حفاظت از گونههاى حيوانى در حال

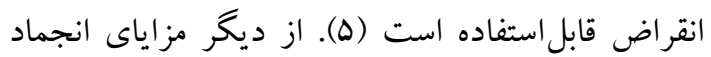
بافت تخمدان اينكه تعداد فراوانى فوليكول بدوى و اوليه الفيه ذخيره مىشود، نياز به تأخير در روند درمان سرطان نيست

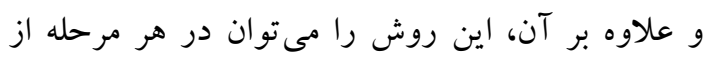
سيكل توليدمثلى انجام داد (9،V).

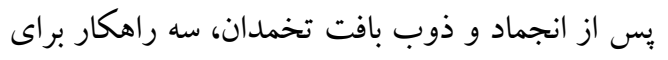
رشد فوليكولهاى موجود در بافت وجود دارد كه عبارتاند از: 1. كشت آزمايشگاهى قطعات بافتى؛ r. كشت

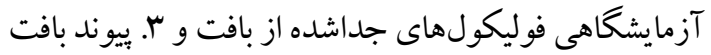
منجمد و ذوبشده به خود فرد (اتو كرافت) يا به كونه ديخر

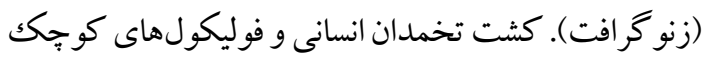
جداشده از بافت انجمادى در مرحلة تحقيقاتى هستندو هنوز بالينى نشدهاند (ᄉ). از سال سوما تاكنون، مطالعات متعددى روى ييوند بافت تخمدان در حيوانات و حتى انسان صورت

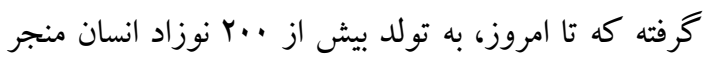

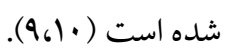


ا. در مرحلة اول، تخمدانها در محلول تعادلى حاوى HEPES tissue culture medium (HTCM) ضديخ اتيلن كليكول و دىمتيل سولفو كسايد (DMSO) تهيه شده از شركت سيخما (D2650, sigma) (هر كدام به ميز ان ه/ درصد) و · r درصد آلبومين سرم انسانى (HSA) قرار داده و به مدت ها دقيقه در دماى محيط، روى لرزاندهء الكتريكى (شيكر) گذاشته شدند.

ז. در مرحله دوم، تخمدانها وارد محلول انجمادى دوم حاوى HTCM، تر كيب دو ضديخ اتيلن كليكول و DMSO كرديد و به مدت ها دقيقه روى شيكر قرار داده و بلافاصله در نيتروزن مايع (C¹96-) به مدت ·م دقيقه فروبرده شدند؛ سُس تخمدانها از داخل نيتروزن خارج و بلافاصله وارد مرحله ذوب گرديدند. ذوب در سه مرحله صورت كرفت: ا. ابتدا تخمدان در محلول HTCM و 1 مول سو كروز به مدت ا دقيقه و در دماى C³7 قرار كرفت؛ ז. سبِ تخمدان در محلولHTCM و ه/ • مول سوكروز به مدت ه دقيقه و در دماى اتاق نخهدارى شد؛ س.حدر مرحلة سوم، تخمدان در محلول HTCM بهتنهايى، به مدت دقيقه و در دماى اتاق قرار گرفت.

انكيسوله كردن بافت تخمدان با هيدروزل هيالورونيكك اسيد: در گروه كنترل كه نيازى به كبسوله كردن بافت تخمدان نبود، تخمدان انجمادى_ذوبشدهُ هر رت به داخل عضله بشتى بزرگك همان رت بيوند زده شد. در كروه آزمايشى از كيت هيدروزل اسيد هيالورونيك (America,Advance BioMatrix) كيت از سه جزء اصلى Gelin-STM Heprasil@ و Extralink® تشكيل شده است. براى كار با اين كيت، بر إسى طبق يروتكل، هريكك اجزاى آن در آب ديونيزه موجود در F. كيت حل كرديد؛ سيس داخل يك يترى ديش استريل ميكروليتر از Heprasil و ·f ميكروليتر از Gelin-S تركيب

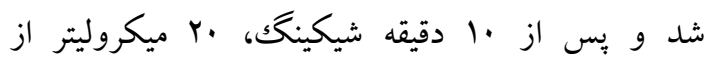
Extralink در داخل آن قرار داده شد و به مدت ·r دقيقه روى صفحء
مىافتد؛ در مرحلة سوم، اين سيخنالهاى مولكولى ايجادشده بهمنظور يكهارجهسازى به مراكز تنظيم كننده مىرسند تا تصميم نهايى مرك يا زندگى گر فته شود. اخر سلول از اين مرحله عبور كند، مرحله جهارم شامل مولكولهاى مؤثر موردنياز براى از بين بردن سلول است

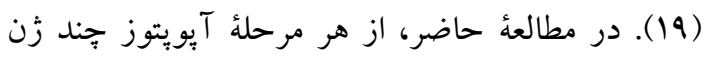
انتخاب و ميزان بيان هريكك بررسى شد.

\section{مواد و روش ها - اث}

اواركتومى و انجماد-ذوب بافت تخمدان: در اين

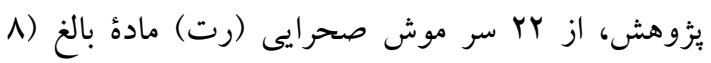

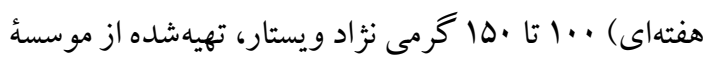
تحقيقاتى پِاستور (موسسة ياستور، ايران، تهران) استفاده

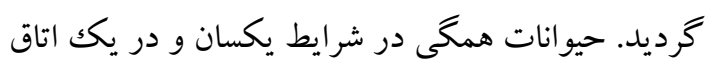
كنترلشده از نظر حرارت و رطوبت و در سيكل r ا ساعت نور و Y ا ساعت تاريكى نخهدارى شدند. شر ايط نخهدارى و مراحل جراحى به تأييد كميته اخلاق دانشگاه تربيت مدرس (كد اخلاق: DYII YFYq) رسيد. يكك هفته ييش از شروع جراحى ها، براى اطمينان از داشتن سيكل توليدمثلى مرتب، روزانه از همهُ موشهاى صحرايى اسمير وازٔن تهيه شد. موشهاى صحر ايى دار ای دست كم ب سيكل استروس مرتب متوالى، درحالى كه در مرحلة دىاستروس سيكل توليدمثلى خود بودند، براى انجام جراحى انتخاب و به دو كروه كنترل (ييوند بافت تخمدان انجمادى بدون هيدروزل اسيد هيالورونيكك؛ VT) و كروه آزمايشى (ييوند بافت تخمدان انجمادى كيسولهده در هيدروزل اسيد هيالورونيكك به تنهايى؛ VT+HA) تقسيم كرديدند. موش هاى صحر ايى بلهوسيلة داروهاى كتامين ( •ه ه (mg/kg) و زايلازين (ه ه m/kg) بيهوش شدند؛ سبس تخمدانهاى دو طرف از بدن رتها خارج گرديد (اواركتومى) و تخمدانهاى سمت راست سريعاً منجمد شدند. فرمول محلول انجمادى كه براى هر دو گروه استفاده گرديد، بر

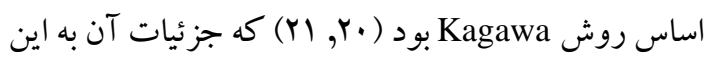
شرح است: 
آكارز؛ د. حذف آلودگى DNA رنومى با كيت DNA

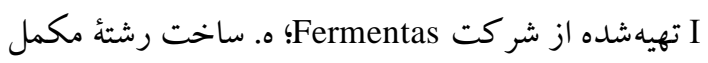
mRNA با استفاده از كيت سنتز cDNA شركت Fermentas .Biosystems) Real Time PCR يرايمرها توسط نرمافزار كامييوترى Allel ID و

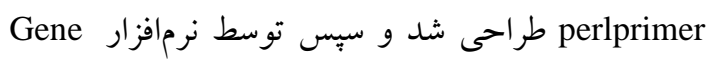

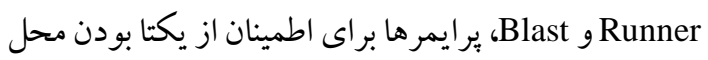

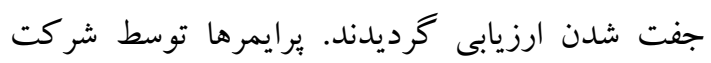

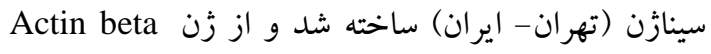

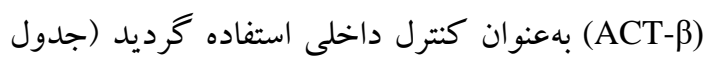

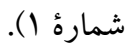
آناليز آمارى دادهها: نتايج بهدست آمده از آزمايشهاى

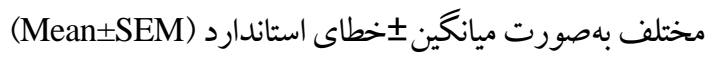

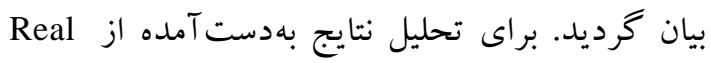

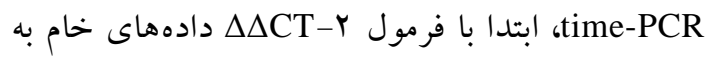
دادههاى قابل تفسير تبديل شد. بهمنظور مقايسٔ ميانخين

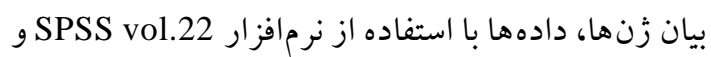

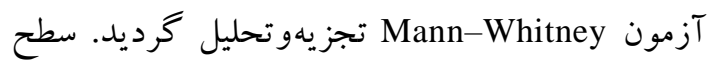
معنى دارى P<0.05 در نظر خر فته شد.
گرم (Tokai-Hit thermoplate, Japan) قرار گرفت. دماى rV درجة صفحة كرم باعث زلهاى شدن اين سه

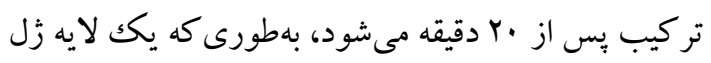

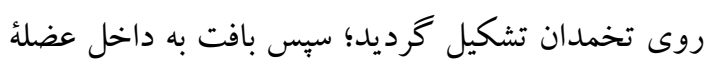

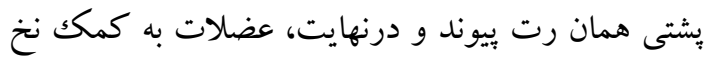

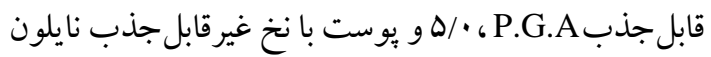
F/• بخيه زده شد.

بررسى ميزان بيان زنهاى آيويتوز: براى اين منظور،

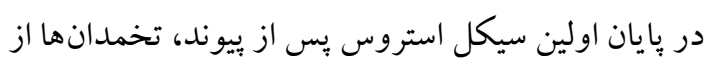

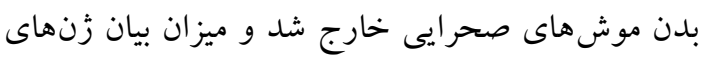
| آبويتوزى ازجمله P53, c-Myc

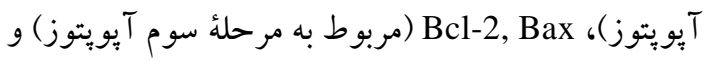
Caspase3 كمى Real Time PCR با يكديخر مقايسه گر ديد. مر احل بررسى مولكولى بهاينترتيب صورت كرفت: الف. استخراج RNA به روش دستى و با استفاده از ترايزول (Sigma, St. Louis, MO) استفاده از جذب نورى به كمك دستكاه اسبكتروفتومتر نانودراب (Thermo Scientific, Wilmington, DE)؛ ج. بررسى كيفيت RNA با استفاده از الكتروفورز زل

جدول شماره ا. ويزگى بر ايمرهاى اختصاصى طر احى شده

\begin{tabular}{|c|c|c|c|c|c|}
\hline $\begin{array}{c}\text { Annealing } \\
\text { temperature }\left({ }^{0} \mathrm{C}\right)\end{array}$ & $\begin{array}{l}\text { Fragment } \\
\text { size(bp) }\end{array}$ & $\begin{array}{c}\text { Accession } \\
\text { number }\end{array}$ & Primer pair sequences & $\begin{array}{l}\text { Target } \\
\text { gene }\end{array}$ & رديف \\
\hline $\begin{array}{l}56.56 \\
57.28\end{array}$ & 177 & NM_031144.3 & $\begin{array}{l}\text { F:CGTTGACATCCGTAAAGACC } \\
\text { R:ATAGAGCCACCAATCCACAC }\end{array}$ & ACT- $\beta$ & 1 \\
\hline 55.67 & 155 & NM_012603.2 & $\begin{array}{l}\text { F: CTATTTGGGGACAGTGTTCTC } \\
\text { R: GGTCATAGTTCCTGTTAGCG }\end{array}$ & $\mathrm{c}-\mathrm{Myc}$ & r \\
\hline $\begin{array}{l}54.86 \\
55.07\end{array}$ & 121 & NM_030989.3 & $\begin{array}{l}\text { F: CCCTGAAGACTGGATAACTG } \\
\text { R: GGGCAGAATATCATCTGGAG }\end{array}$ & P53 & r \\
\hline $\begin{array}{l}58.58 \\
57.17\end{array}$ & 139 & NM_017059.2 & $\begin{array}{l}\text { F: TTTGCTACAGGGTTTCATCCAG } \\
\text { R: GTCCAGTTCATCGCCAATTC }\end{array}$ & Bax & $f$ \\
\hline $\begin{array}{l}59.18 \\
57.77\end{array}$ & 169 & NM_016993.1 & $\begin{array}{l}\text { F: GAGAGCGTCAACAGGGAGAT } \\
\text { R: ACAGCCAGGAGAAATCAAACA }\end{array}$ & Bcl-2 & $\Delta$ \\
\hline $\begin{array}{l}56.27 \\
55.91\end{array}$ & 200 & NM_012922.2 & $\begin{array}{c}\text { F: ATGGACAACAACGAAACCTC } \\
\text { R: GTACCATTGCGAGCTGAC }\end{array}$ & Caspase 3 & 4 \\
\hline
\end{tabular}




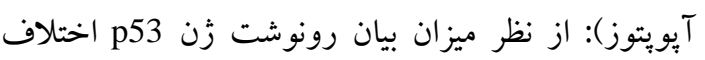
معنادارى ميان دو گروه مشاهده نشد؛ اما ميزان بيان

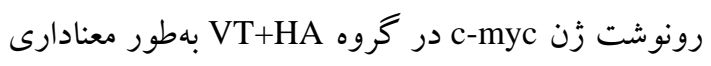
كمتر از خروه VT بود (P<0.05) (شكل شماره (1) ). بيان زنهاى Bcl-2 و Bax (مربوط به مرحلة سوم

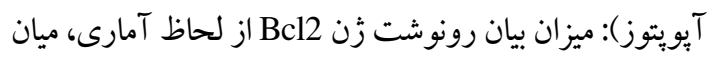

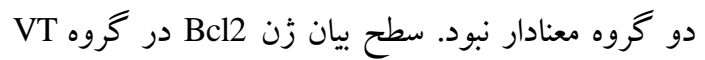

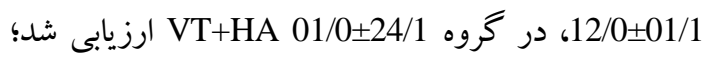

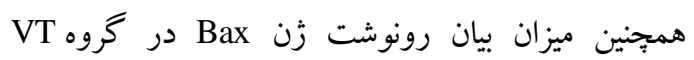

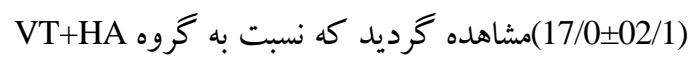
(13/0土78/0) اين اختلاف معنادار نبود. نسبت بيان رونوشت زنهاى Bcl2 و Bcl2/Bax) نيز ميان گروهها با يكديخر مقايسه شد. بهاين ترتيب، سطح

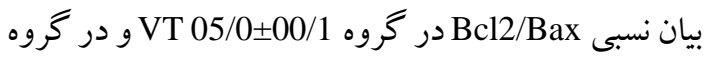
Vود، هرجند اين اختلاف از لحاظ

$$
\text { Tارى معنادار نبود (شكل شمارة Y). }
$$

بيان زن Caspase3: ميزان بيان زن Caspase3 در گروه

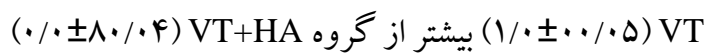
بود؛ اما اختلاف آمارى معنادارى ميان دو گروه ديده نشد (شكل شماره: (r)

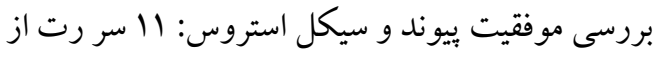

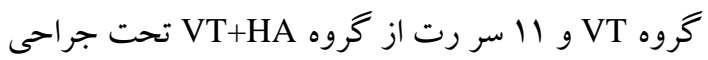

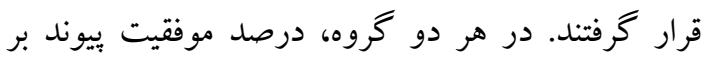

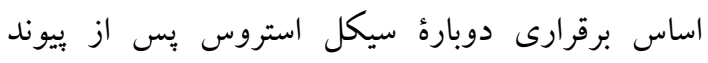

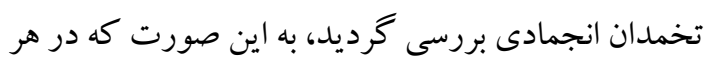

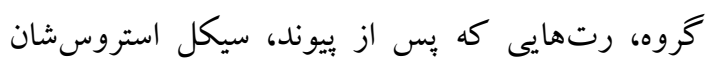

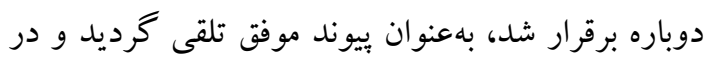

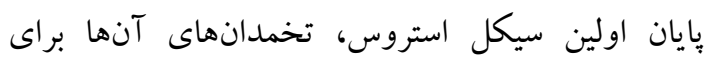

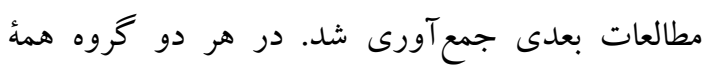

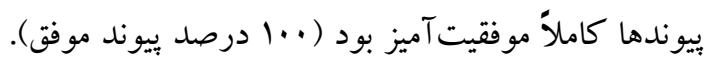
نتايج مربوط به شمارش فوليكولى اين مطالعه در مجلهُ Biopreservation and Biobanking زنهاى) مربوط به مرحلة دوم P53, c-Myc آيويتوز (، Bcl-2, Bax(مربوط به مرحلة سوم آيويتوز) و Caspase3

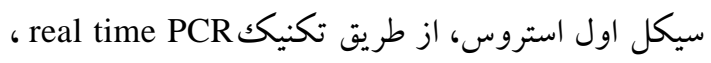

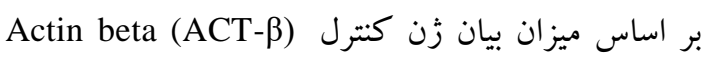

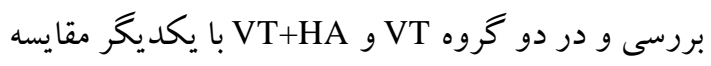

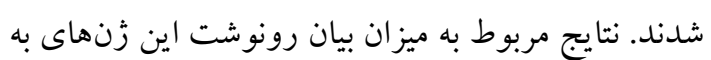
شرح ذيل است:

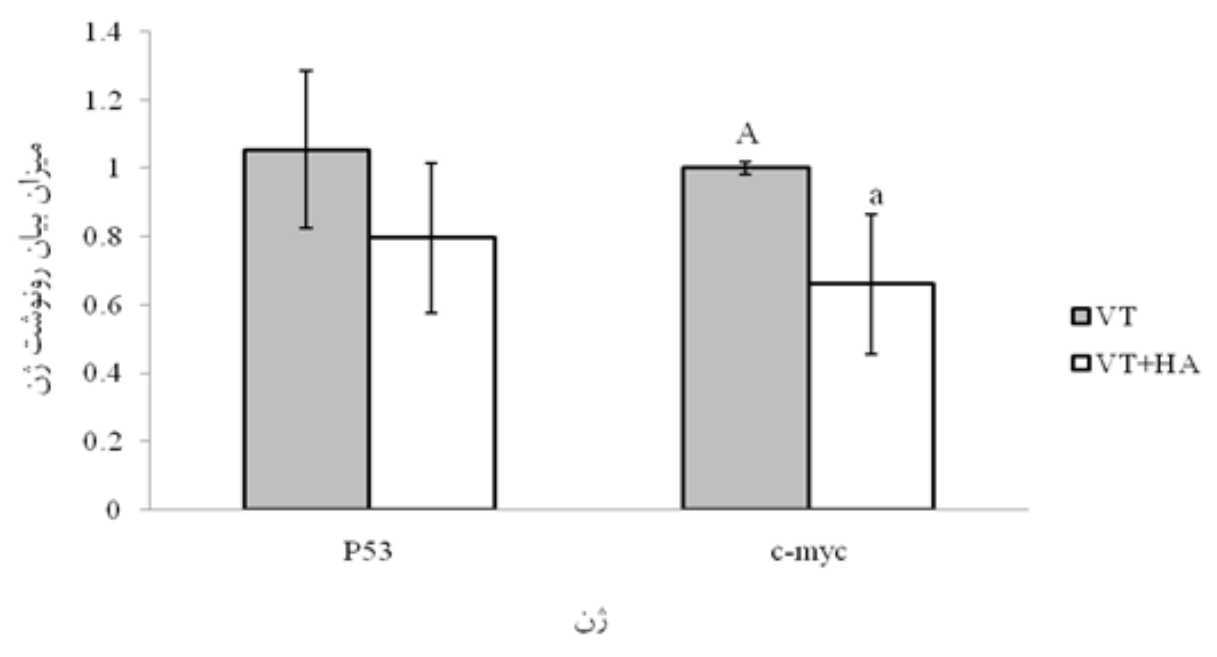

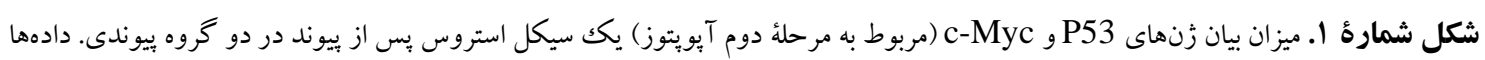

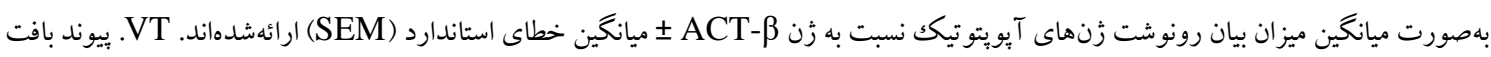

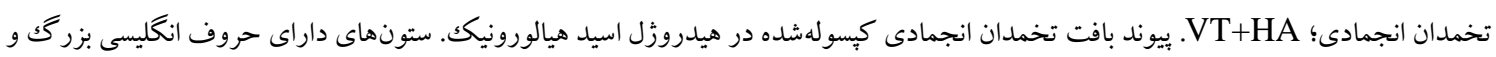
كوجكك مشابه (A a (a با يكديخر اختلاف معنادار دارند (P<0.05). 


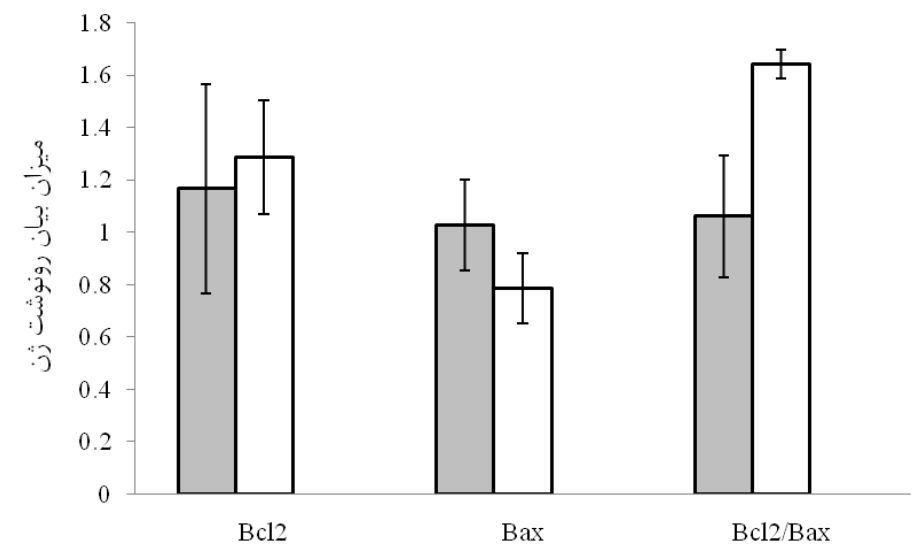

aVT

口VT+HA

ثن

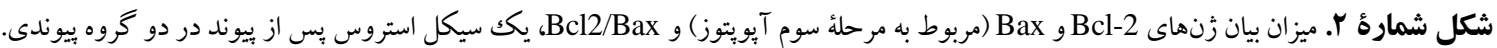

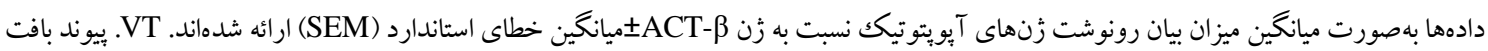

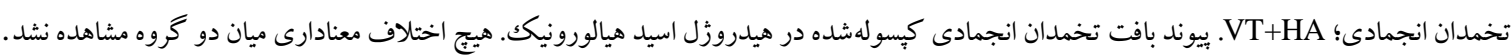

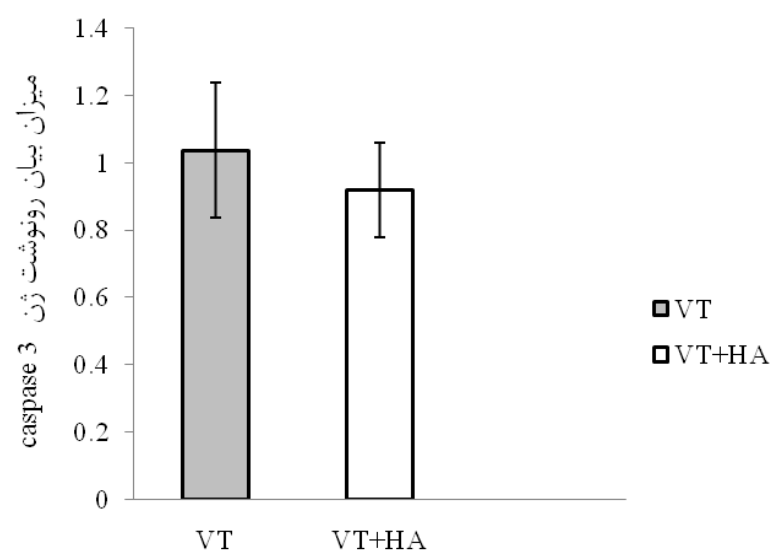

كروه

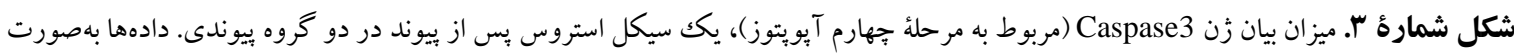

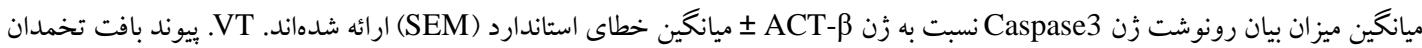

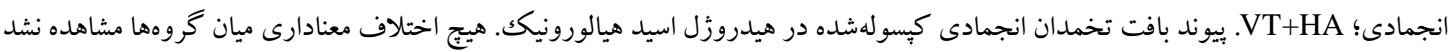

از هيدروزل اسيد هيالورونيك با خاصيت ركَزايى، با هدف سرعت بخشيدن به فرايند آنثيوزنز، كاهش آيويتوز و حفظ ذخاير فوليكولى يس از ييوند بافت تخمدان انجمادى رت استفاده شد. بالينحال، كاربرد هيدروزل اسيد هيالورونيكك بهتنهايى در ميزان موفقيت ييوند تغييرى ايتجاد نكرد و در هر دو كروه درصد موفقيت بيوند يكسان بود.

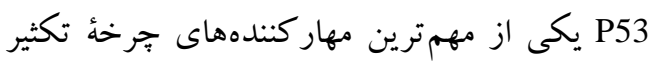
سلولى است كه آن را محافظ زنوم نيز مىنامند. اين مهند

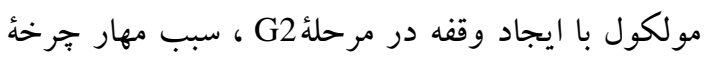

\section{بحث و نتيجه كيرى}

موفقيت ويوند بافت تخمدان هتروتوييك (بدون

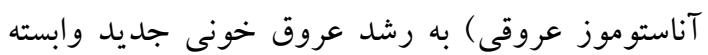
است. رشد سريعتر عروق سبب كاهش صدمات

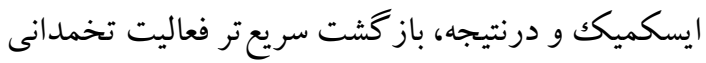

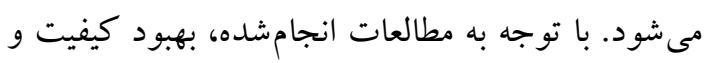

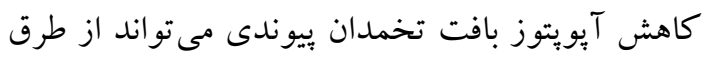

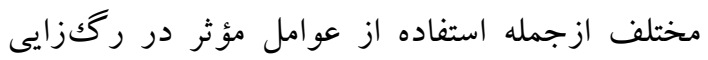

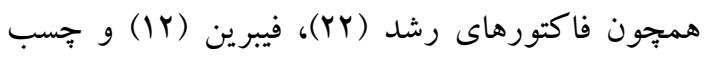

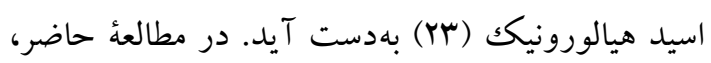


اين خانواده در يستانداران جهارده عضو دارد كه يازده عضو آن آنزيمهاى انسانى هستند. اين آنزيمها مسير

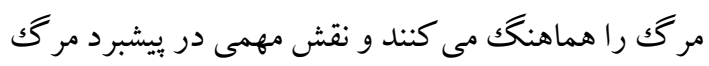
سلولى دارند (YN). كاسيازها مربوط به مرحله جهارم

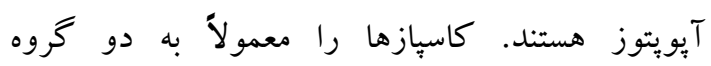

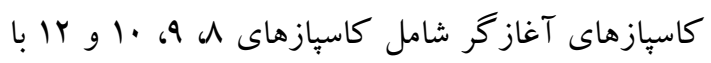
يرودمين طويل و كاسيازهاى اجر اكننده شامل كاسبازهاى r، 9 و V با برودمين كو تاه تقسيم مي كنند. درواقع، كار

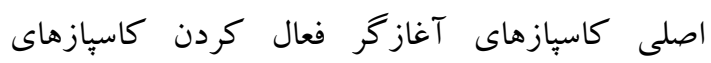
اجراكننده است (Yq). در اين مطالعه، ميزان رونوشت إنسي

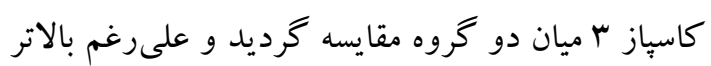
بودن سطح بيان اين زن در كروه VT ، تفاوت معنادارى ميان دو گرووه مشاهده نشد. اين نتايج نشان مىدهد على رغم معنادار نبودن بسيارى از تفاوتها، در همد زنها الكوى بيان يكسانى مشاهده شد و هيدروزل اسيد هيالورونيك توانست فرايند آيويتوز را يس از بيوند، نسبت به گروه بدون كِيسول كاهش دهد. با توجه به خاصيت رگكزايى هيالورونيك اسيد (•r)، اين نتيجه دور از انتظار نيست؛ بنابراين بيشنهاد مىشود بيان اين زنها در زمان طولانىترى بس از بيوند نيز ارزيابى گردد؛ زيرا در

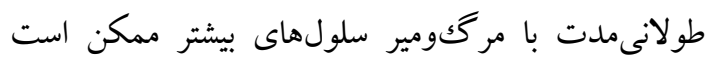
تفاوت بيان زنها بيشتر مشهود شود.

\section{تشكر و قدردانى}

نويسند گان مقاله از حمايتهاى مادى و معنوى معن

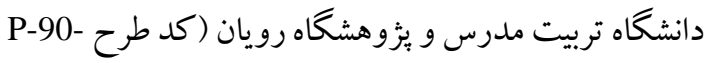
284) و صندوق حمايت از يثوهشخران و فناوران كشور كمال تشكر را دارند.

\section{تعارض منافع}

نويسند كان اعلام مى كنند كه تضاد منافعى در اين

مطالعه وجود ندارد.

كد اخلاق: 52112429
سلولى مىشود و با القاى آيويتوز از ايجاد تومور جلو گيرى مى كند. تخريب DNA عامل اصلى فعاليت اين

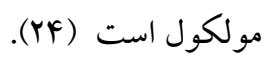
يكى ديخر از يروتئين هايى است كه در تنظيم c-Myc رشد سلولى و آيويتوزيس نقش دارد. تقريباً علت يككسوم c-Myc سرطانهاى انسانى ناشى از بيان تنظيمنشدهُ برو تئين است و بيان بيشازحد اين زن در مراحل بيشرفته برخى از

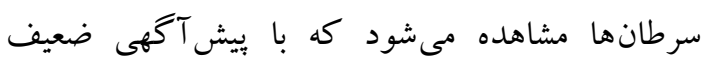
بيمارى ارتباط مستقيم دارد (Yه). در اوايل دهذ .999، ايوان و همكارانش عنوان كردند كه c-Myc در فرايند آيويتوز نيز نقش فعالى دارد، بهطورى كه در سلولهاى نرمال بيان بايينى از c-Myc هست. در مقابل، سلولهايى كه بيان c-Myc در آنها افزايش مىيابد، محكوم به مر گكاند و تحت فرايند آيويتوز قرار مى گيرند (Y4). در مطالعهُ حاضر، ميزان بيان زنهاى P53و و كه هر دو در مرحلة دوم آيويتوز بيان مىشوند، در گروه VT بالاتر از خروه VT+HA بود؛ اما تنها از نظر بيان زن ع-Myc ميان دو گروه اختلاف معنادار بود. به هر حال، اين موضوع نشان مىدهد هيالورونيكك اسيد توانسته است بيان زنهاى مرحلهُ دوم آيويتوز را كاهش دهد.

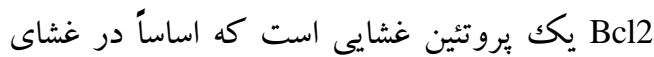
خارجى ميتو كندرى قرار دارد. در يستانداران نوزده عضو از خانواده Bcl2 شناسايىشده است كه با توجه به فعاليت و ساختار، به سه دسته تقسيمشدهاند: دستهُ اول. اعضاى ضدآيويتوز كه مهمترين آنها عبارتاند از Bcl2 : و Bcl XL دسته دوم. اعضاى يرو آيويتوز كه مى توان از اين كروه به Bax و Bak اشاره كرد؛ دسته سوم. مهمترين اعضاى

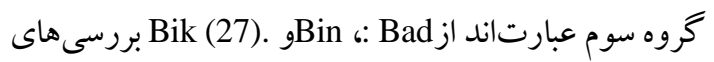
مولكولى انجامشدهُ يكك سيكل يس از ييوند در دو گروه نشان داد كه ميزان بيان زن Bcl2 و Bax اختلاف آمارى معنادارى ميان گروهها نداشت. باينحال، در اين مرحله نيز كروه داراى هيالورونيكك اسيد سطح يايينترى از بيان زنهاى آيويتوزى را داشته است.

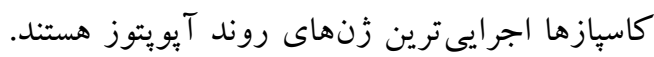




\section{References}

1. Demeestere I, Simon P, Emiliani S, Delbaere A, Englert Y. Orthotopic and heterotopic ovarian tissue transplantation. Hum Rep Up2009;15:64965. doi.10.1093/humupd/dmp021.

2. Marin L, Bedoschi G, Kawahara T, Oktay KH. History evolution and current state of ovarian tissue autotransplantation with cryopreserved tissue a successful translational research Journey from 1999 to 2020. Rep Sci 2020:1-8. doi.10.1007/s43032-019-00066-9.

3. Kim S, Lee Y, Lee S, Kim T. Ovarian tissue cryopreservation and transplantation in patients with cancer. Obste Gynecol Sci 2018;61:431. doi. 10.5468/ogs.2018.61.4.431.

4. Donnez J, Dolmans M, Demylle D, Jadoul P, Pirard C, Squifflet J, et al. Restoration of ovarian function after orthotopic intraovarian and periovarian transplantation of cryopreserved ovarian tissue in a woman treated by bone marrow transplantation for sickle cell anaemia case report. Hum Rep 2006;21:183-8. doi.10.1093/ humrep/dei268

5. Santos R, Amorim C, Cecconi S, Fassbender M, Imhof M, Lornage $\mathrm{J}$, et al. Cryopreservation of ovarian tissue: an emerging technology for female germline preservation of endangered species and breeds. Anim Rep Sci2010;122:151-63. doi.10.1016/j.anireprosci.2010.08.010

6. Oktay K. Ovarian tissue cryopreservation and transplantation preliminary findings and implications for cancer patients. Hum Rep Up 2001;7:526-34 . doi.10.1093/humupd/7.6.526

7. Fathi R, Rezazadehvalojerdi M, Salehnia M, Ebrahimi B, Salmanyazdi R. Ovarian tissue transplantation advantages disadvantages and upcoming challenges. J Mazandaran Uni Med Sci 2014;24:253-65

8. Amorim CA, Curaba M, Van Langendonckt A, Dolmans MM, Donnez J. Vitrification as an alternative means of cryopreserving ovarian tissue. Rep Biomed 2011;23:160-86

9. Hossay C, Donnez J, Dolmans MM. Whole ovary cryopreservation and transplantation: a systematic review of challenges and research developments in animal experiments and humans. J Clin Med 2020;9:3196. doi.10.3390/jcm9103196

10. Roness H, Meirow D. Fertility preservation follicle reserve loss in ovarian tissue transplantation. Reproduction 2019;158:35-44. doi.10.1530/REP19-0097.

11. Damous LL, Silva SMd, Lopes RAM, Sakano CRdSB, Simoes MdJ, Montero EFDS. Study on the vaginal smear of rats submitted to autologous ovarian transplant impact of remote ischemic preconditioning. Acta Cir Brasile2009;24:387-92. doi.10.1590/S0102-86502009000500009

12. Gao JM, Yan J, Li R, Li M, Yan LY, Wang TR, et al. Improvement in the quality of heterotopic allotransplanted mouse ovarian tissues with basic fibro

13. Liu L, Wood G, Morikawa L, Ayearst R, Fleming C, McKerlie C. Restoration of fertility by orthotopic transplantation of frozen adult Mouse ovaries. Hum Rep 2008;23:122-8. doi.10.1093/ humrep/dem348
14. Shiraztehrani A, Mazoochi T, Akhavantaheri M, Salehnia M. The effects of ovarian encapsulation with alginate hydrogel on morphology and follicular count of vitrified Mouse ovary. J Feyz2019;23:467-75

15. Tehrani AS, Mazoochi T, Taheri MA, Aghadavood E, Salehnia M. The effects of ovarian encapsulation on morphology and expression of apoptosis related genes in vitrified Mouse ovary. J Rep Inf2021;22:23 . doi.10.18502/jri.v22i1.4992

16. Gao J, Huang Y, Li M, Zhao H, Zhao Y, Li R, et al. Effect of local basic fibroblast growth factor and vascular endothelial growth factor on subcutaneously allotransplanted ovarian tissue in ovariectomized Mice. PLos One 2015;10: 134035. doi.10.1371/journal.pone.0134035

17. Fraser J, Laurent T, Laurent U. Hyaluronan: its nature, distribution, functions and turnover. $\mathrm{J}$ Int Med 1997;242:27-33. doi.10.1046/j.13652796.1997.00170.x

18. Sattar A, Rooney P, Kumar S, Pye D, West DC, Scott I, et al. Application of angiogenic oligosaccharides of hyaluronan increases blood vessel numbers in rat skin. J Invest Dermatol1994;103:576-9. doi.10.1111/1523-1747. ep12396880

19. Morita Y, Tilly JL. Oocyte apoptosis: like sand through an hourglass. Dev Biol 1999;213:1-17. doi.10.1006/dbio.1999.9344.

20. Kagawa N, Silber S, Kuwayama M. Successful vitrification of bovine and human ovarian tissue. Rep Biomed 2009;18:568-77. doi.10.1016/s14726483(10)60136-8.

21. Akhavan Taheri M, Rezazadeh Valojerdi $M$, Ebrahimi B. Intramuscular autotransplantation of vitrified rat ovary encapsulated with hyaluronic acid hydrogel. Biopres Biobank2016;14:114-21. doi.10.1089/bio.2015.0021

22. Wang L, Ying YF, Ouyang YL, Wang JF, Xu J. VEGF and bFGF increase survival of xenografted human ovarian tissue in an experimental Rabbit model. J Assist Rep Genet 2013;30:1301-11. doi.10.1007/s10815-013-0043-9

23. Tavana S, Azarnia M, Valojerdi MR, Shahverdi A Hyaluronic acid based hydrogel scaffold without angiogenic growth factors enhances ovarian tissue function after autotransplantation in Rats. Biomedical Mate2016;11: 55006. doi.10.1088/ 1748-6041/11/5/055006

24. Höpker K, Hagmann H, Khurshid S, Chen S, Schermer B, Benzing T, et al. Putting the brakes on p53 driven apoptosis. Cell Cycle2012;11:4122-8. doi.10.4161/cc.21997

25. Prendergast GC. Mechanisms of apoptosis by $\mathrm{c}$ Myc. Oncogene1999;18:2967-87. doi.10.1038/ sj.onc. 1202727

26. Evan GI, Wyllie AH, Gilbert CS, Littlewood TD, Land $\mathrm{H}$, Brooks M, et al. Induction of apoptosis in fibroblasts by c myc protein. Cell1992;69:119-28. doi.10.1016/0092-8674(92)90123-T

27. Dlamini Z, Mbita Z, Zungu M. Genealogy, expression, and molecular mechanisms in apoptosis. Pharmacol Ther2004;101:1-15. d doi.10.1016/j.pharmthera.2003.08.005

28. Schwerk C, Schulze-Osthoff K. Non-apoptotic 
functions of caspases in cellular proliferation and differentiation. Biochem Pharmacol. 2003;66(8): 1453-8. doi: 10.1016/S0006-2952(03)00497-0

29. Köhler C, Orrenius S, Zhivotovsky B. Evaluation of caspase activity in apoptotic cells. J Immunol Meth2002;265:97-110. doi.10.1016/S0022-1759 (02)00073-X
30. Tavana S, Valojerdi MR, Azarnia M, Shahverdi A Restoration of ovarian tissue function and estrous cycle in rat after autotransplantation using hyaluronic acid hydrogel scaffold containing VEGF and bFGF. Growth Fact 2016;34:97-106. doi.10.1080/08977194.2016.1194835 